\title{
Comparative Study on the Effects of Surfactants on the Electroless Copper Coated Solar Cell and Optimizing Its Process Parameters
}

\author{
M. Jeevarani and R. Elansezhian \\ Mechanical Engineering Department, Pondicherry Engineering College, Pondicherry 605014, India \\ Correspondence should be addressed to M. Jeevarani; informjeeva@gmail.com
}

Received 21 January 2014; Revised 4 April 2014; Accepted 24 April 2014; Published 5 June 2014

Academic Editor: Devis Di Tommaso

Copyright (c) 2014 M. Jeevarani and R. Elansezhian. This is an open access article distributed under the Creative Commons Attribution License, which permits unrestricted use, distribution, and reproduction in any medium, provided the original work is properly cited.

\begin{abstract}
An experimental investigation on optimizing process parameters in the electroless copper coatings on solar photovoltaic cells under specific coating conditions has been carried out and reported. Coating parameters such as $\mathrm{pH}$, temperature, and surfactants concentration were varied, and corresponding coating thickness and voltage were measured. To optimize the above parameters, design of experiment was conducted using full factorial method. The $\mathrm{pH}$ was varied at 4 different values such as 4-5, 5-6, 8-9, and 9-10 and temperature was varied at different values such as $75^{\circ} \mathrm{C}, 80^{\circ} \mathrm{C}, 85^{\circ} \mathrm{C}$, and $90^{\circ} \mathrm{C}$. The two different surfactants such as Sodium Do-decyl sulfate and Cetyl tri ammonium bromide were added and their concentration was varied from $0-1.5 \mathrm{~g} / \mathrm{L}$ to $0-1.8 \mathrm{~g} / \mathrm{L}$, respectively. When $\mathrm{pH}$ was $8-9$, the coating thickness was maximum of $12 \mu \mathrm{m}$ and $11.63 \mu \mathrm{m}$ and it was minimum of $3 \mu \mathrm{m}$ and $2.6 \mu \mathrm{m}$, when $\mathrm{pH}$ was at $4-5$ for Sodium Do-decyl sulfate and Cetyl tri ammonium bromide respectively. The coating thickness increases up to $12 \mu \mathrm{m}$ when the temperature was $85^{\circ} \mathrm{C}$ and further increase in temperature destabilizes the electroless bath. The coating thickness was a maximum of $11.25 \mu \mathrm{m} / \mathrm{hr}$ and $10.53 \mu \mathrm{m} / \mathrm{hr}$, when the Sodium Dodecyl sulfate and Cetyl tri ammonium bromide concentrations were $1.2 \mathrm{~g} / \mathrm{L}$ and $1.5 \mathrm{~g} / \mathrm{L}$, respectively. The increased coating thickness of solar cells imparts increased open circuit voltage from $0.43 \mathrm{~V}$ to $0.65 \mathrm{~V}$. The detailed experimental results and their analysis are presented in the main paper.
\end{abstract}

\section{Introduction}

Photovoltaic cells convert sunlight directly into electricity. A solar cell (also called photovoltaic cell or photoelectric cell) is a solid state electrical device that converts the energy of light directly into electricity by the photovoltaic effect. The manufacturing of high-efficiency crystalline-silicon (c-Si) solar cells involves advanced technologies and sophisticated equipment not available in third-world country laboratories. Today, the conversion efficiency of advanced crystallinesilicon (c-Si) solar cells is up to $25 \%$. But their manufacturing involves rather advanced technologies and equipment not available in most third-world country laboratories.

Recently, electroless deposition of copper, using only a chemical bath, has received considerable attention. Major advantages over the electroless deposition process include the formation of a uniform deposit on irregular surfaces, direct deposition on surface activated nonconductors, and the formation of less porous and more corrosion resistant deposits [1]. Copper plating can change the appearance, dimensions, or electrical conductivity of a metal part. In the presence of $\mathrm{CTAB}$, at lower concentrations (up to $0.6 \mathrm{~g} / \mathrm{L}$ ), coalescence of nickel particles has been deposited on the substrate surface, and, at the higher concentration (above $0.6 \mathrm{~g} / \mathrm{L}$ ), a uniformly improved surface finish of the deposited layer resulted [2]. The cost of using this approach is significantly lower than PVD and CVD processes, although there have been some studies on the electroless $\mathrm{Cu}$ properties.

High-efficiency silicon solar cells need a textured front surface to reduce reflectance since optical losses due to reflectance of incident solar radiation are one of the most important factors which limits their efficiency. Here electroless process was used to texture the silicon surface and also for the coating on the grid surface. From [3] copper 
TABLE 1: Control parameters.

\begin{tabular}{lcc}
\hline Parameters & High value & Low value \\
\hline $\mathrm{pH}$ & 10 & 4 \\
Temperature & $90^{\circ} \mathrm{C}$ & $75^{\circ} \mathrm{C}$ \\
Surfactant concentration (SDS) & $1.2 \mathrm{~g} / \mathrm{L}$ & $0 \mathrm{~g} / \mathrm{L}$ \\
Surfactant concentration (CTAB) & $1.5 \mathrm{~g} / \mathrm{L}$ & $0 \mathrm{~g} / \mathrm{L}$ \\
\hline
\end{tabular}

indium diselenide (CIS) has been deposited on molybdenum substrates using electroless process.

Surfactants are surface active agents that lower the surface tension of a liquid, allowing easier spreading, and lower the interfacial tension between two liquids. Surfactants reduce the surface tension of water by adsorbing at the liquid-gas interface. Many surfactants assemble in the bulk solution into aggregates known as micelles. The concentration at which surfactants begin to form micelles is known as the critical micelle concentration or CMC. A surfactant can be classified by the presence of formally charged groups in its head. A nonionic surfactant has no charge groups in its head and an ionic surfactant carries a net charge. If the charge is negative, the surfactant is called anionic; if the charge is positive, it is called cationic. Tripathy et al. [4] studied the effect of addition of sodium dodecyl sulfate (SDS) on the surface morphology and reported that SDS addition in the bath improved the surface morphology. Medina-Valtierra et al. [5] studied the influence of cetyl trimethyl ammonium bromide (CTAB) on the roughness of Titania sol-gel films and reported that the sol-gel films prepared with surfactant showed a granular microstructure and are composed of irregular particles on the surface and enhanced the photocatalytic activity. However, limited data are available concerning the effects of anionic surfactant SDS and cationic surfactant $\mathrm{CTAB}$ on the electroless copper deposits. In this study, the effect of surfactants SDS and CTAB addition on the coating thickness, microstructure, and voltage generation of coppercoated multicrystalline solar cell samples was investigated.

\section{Introduction to Design of Experiments}

Design of experiments (DOE) refers to experimental methods used to quantify indeterminate measurements of factors and interactions between factors statistically through the observance of forced changes made methodically as directed by mathematically systematic tables.

2.1. Full Factorial Design. A full factorial design contains all possible combinations of the set of factors [6]. This is the most conservative design approach, but it is also the most costly in experimental resources. The full factorial designer supports both continuous factors and categorical factors with up to nine levels. In full factorial design, experiment is performed at every combination of the factor levels. The sample size is the product of the number of levels of the factors.

2.2. Control Parameters and Their Levels. Preliminary experiments are made to fix the control parameters. The control
TABLE 2: Design matrix for electroless copper coating process.

\begin{tabular}{lcccc}
\hline $\begin{array}{l}\text { Sl. } \\
\text { number }\end{array}$ & $\begin{array}{c}\text { Run } \\
\text { label }\end{array}$ & $\mathrm{pH}[\mathrm{a}]$ & $\begin{array}{c}\text { Temperature } \\
{ }^{\circ} \mathrm{C}[\mathrm{b}]\end{array}$ & $\begin{array}{c}\text { Surfactant } \\
\text { concentration } \\
(\mathrm{g} / \mathrm{L})[\mathrm{c}]\end{array}$ \\
\hline 1 & $\mathrm{I}$ & - & - & - \\
2 & $\mathrm{a}$ & + & - & - \\
3 & $\mathrm{~b}$ & - & + & - \\
4 & $\mathrm{c}$ & - & - & + \\
5 & bc & - & + & + \\
6 & ac & + & - & + \\
7 & ab & + & + & - \\
8 & abc & + & + & + \\
\hline
\end{tabular}

parameters and their levels are listed in Table 1. At low $\mathrm{pH}$ value, that is, (4-5), rate of deposition is low and life of bath is high. At high $\mathrm{pH}$ value (9-10), rate of deposition is high and life of bath is low. Hence, $\mathrm{pH}$ value at 8-9 is considered as optimum. At low temperature $\left(75^{\circ} \mathrm{C}\right)$, viscosity of bath is more, so coating is improper on the substrate. At high temperature $\left(90^{\circ} \mathrm{C}\right)$, bath decomposes and affects the coating on the substrate. Hence the proper reaction takes place at $85^{\circ} \mathrm{C}$. When the surfactant is $0 \mathrm{~g} / \mathrm{L}$, no proper coating takes place. When the surfactant concentration is increased to $1.4 \mathrm{~g} / \mathrm{L}$, the bath becomes unstable. So the proper uniform coating takes place at $1.2 \mathrm{~g} / \mathrm{L}$ for SDS and $1.5 \mathrm{~g} / \mathrm{L}$ for CTAB.

2.3. Design Matrix. Table 2 represents the number of experiments conducted. Here + represents the high value of parameters and - represents the low value of parameters. Based on full factorial design, eight experiments have been conductedby varying the $\mathrm{pH}$, temperature, and surfactant concentration (SDS). Another set of eight experiments were conducted by varying the surfactant as CTAB.

\section{Materials and Methods}

3.1. Preparation of the Substrates. The substrates used in this study were multicrystalline solar PV cells each of 0.45 volts capacity, which are turned into the dimension of $78 \times 12 \mathrm{~mm}$. After that, finally, the samples were surface finished and used.

3.2. Cleaning of the Substrates. Prior to the coating, it must be ensured that the substrate is free from any impurities. So cleaning is very important to achieve efficient coating. Cleaning can be carried out with acetone then followed by rinsing in distilled water and then dipped in methanol for 2 minutes.

3.3. Activation/Catalyzation of the Substrate. Tin sensitization followed by palladium activation is an important route to the formation of the catalyst on a variety of substrates [7]. Activation [8] was carried out by the following three steps:

(1) etching by $10 \%$ nitric acid and $10 \%$ of hydrofluoric acid; 


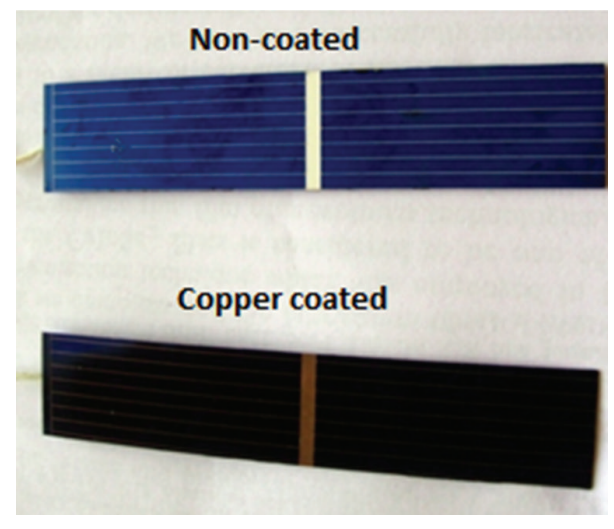

Figure 1: Noncoated and copper coated solar cell samples.

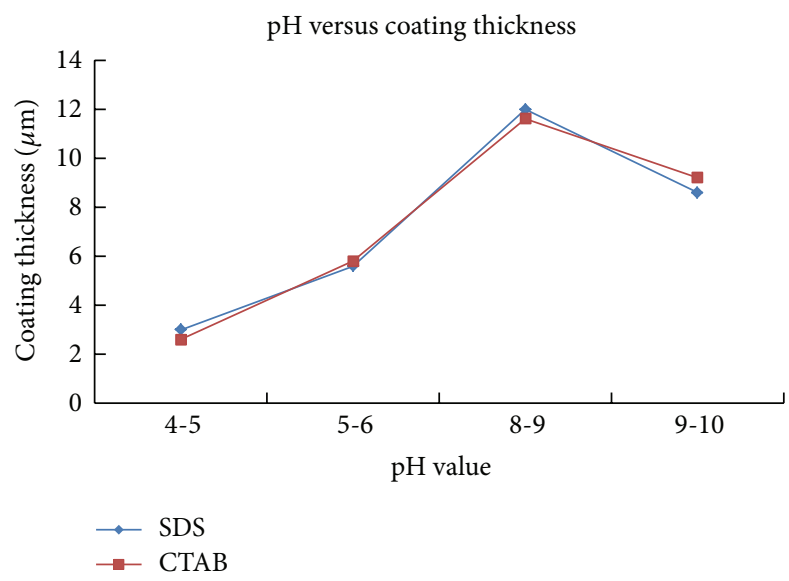

FIGURE 2: Variation of coating thickness with $\mathrm{pH}$.

(2) sensitisation: $10 \mathrm{~g} / \mathrm{L}$ of stannous chloride mixed with $50 \mathrm{~mL} / \mathrm{l}$ of hydrochloric acid;

(3) catalysation: $0.5 \mathrm{~g} / \mathrm{L}$ of palladium chloride mixed with $10 \mathrm{~mL} / \mathrm{l}$ of hydrochloric acid.

Here activation is carried out for 2 minutes and immersed in the electroless bath for 1 hour.

3.4. Experimental Procedure and Operating Conditions. The preliminary experiments were made to fix the control parameter such as $\mathrm{pH}$, temperature, and surfactant concentration. The electroless bath was prepared using different concentrations of surfactants with the variation of $0.15 \mathrm{~g} / \mathrm{L}$. The electroless copper bath consists of $5 \mathrm{~g} / \mathrm{L}$ copper sulphate $\left(\mathrm{CuSO}_{4} \cdot 5 \mathrm{H}_{2} \mathrm{O}\right), 12 \mathrm{~g} / \mathrm{L}$ ethylene diamine tetraacetic acid (EDTA), $1.2 \mathrm{~g} / \mathrm{L}$ (SDS) or $1.5 \mathrm{~g} / \mathrm{L}$ (CTAB), and $5 \mathrm{~mL} / 1$ formaldehyde (HCHO). Temperature of the plating bath was maintained at $80^{\circ} \mathrm{C}\left( \pm 5^{\circ} \mathrm{C}\right)$. The $\mathrm{pH}$ of the bath was maintained between 8 and 9 by adding sufficient quantity of sodium hydroxide pallets as and when required. The electrolyte was heated indirectly by an electrically heated oil bath whose temperature was regulated by a PID controller. The temperature of the oil medium was controlled and monitored using a thermometer. The coating was done for a

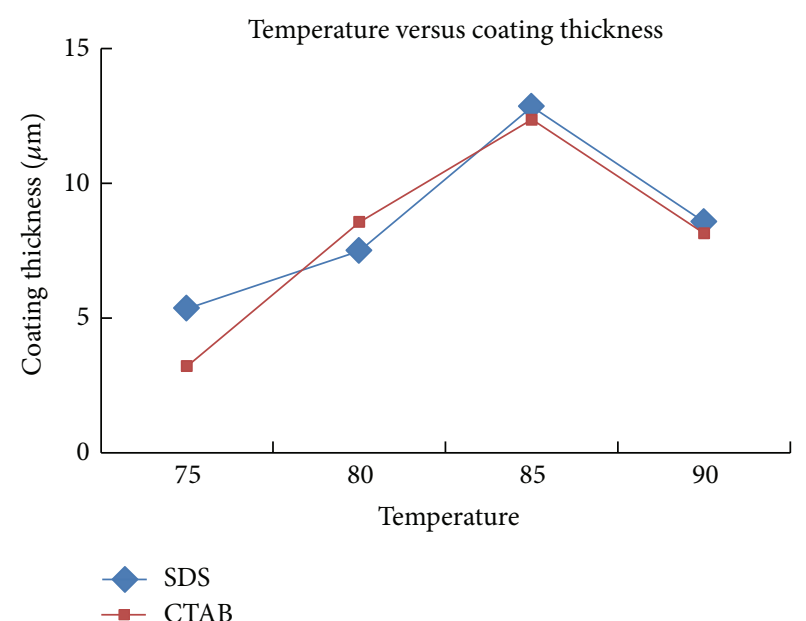

FIGURE 3: Variation of coating thickness with temperature.

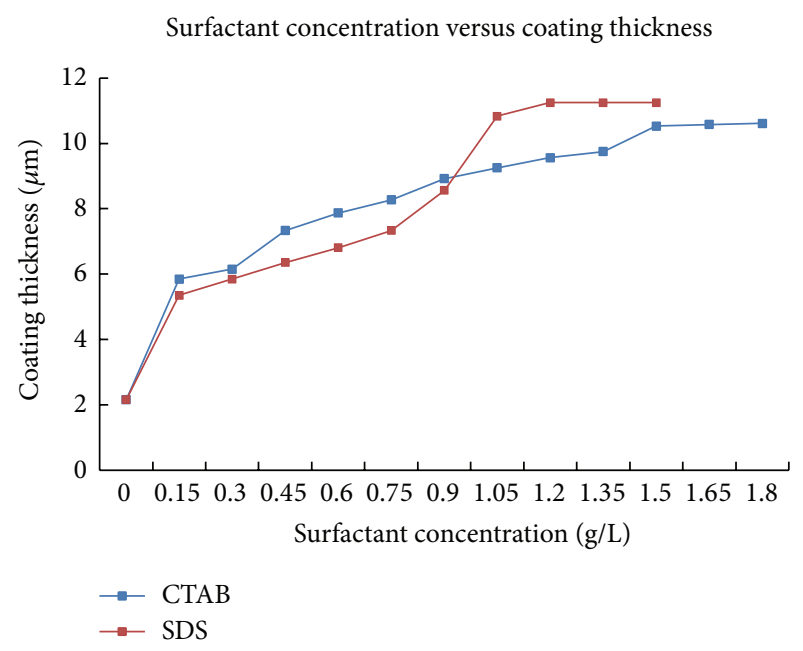

FIGURE 4: Variation of coating thickness with surfactants concentration.

period of $1 \mathrm{~h}$ with total volume of the plating bath restricted to $100 \mathrm{~mL}$ (unless otherwise mentioned). The copper coated solar cell sample was shown along with non coated sample in Figure 1.

\section{Results and Discussion}

4.1. Effect of $p H$ and Temperature on Coating Thickness. Figure 2 shows that when $\mathrm{pH}$ was 8-9, the coating thickness on grid surface was a maximum of $12 \mu \mathrm{m}$ and $11.63 \mu \mathrm{m}$ and that when $\mathrm{pH}$ was at $4-5$, it was a minimum of $3 \mu \mathrm{m}$ and $2.6 \mu \mathrm{m}$ for SDS and CTAB, respectively. Similarly, Figure 3 shows that the coating thickness increases up to $12 \mu \mathrm{m}$, when the temperature was $85^{\circ} \mathrm{C}$, and that further increase in temperature destabilizes the electroless bath, and when temperature was $90^{\circ} \mathrm{C}$, the coating thickness was reduced to $8 \mu \mathrm{m}$ and $7.6 \mu \mathrm{m}$ for SDS and CTAB, respectively. These results follow a similar trend as reported by earlier researchers Hanna et al. [8]. 


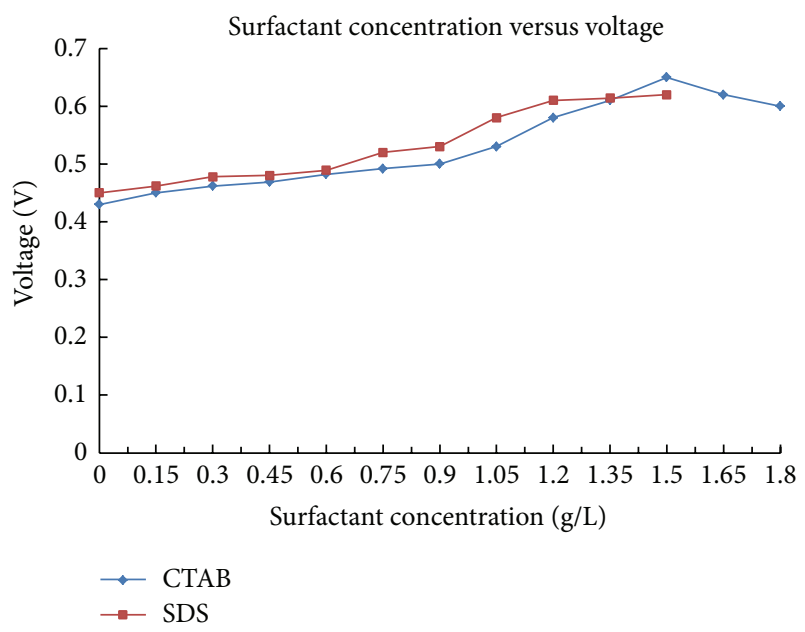

FIGURE 5: Variation of voltage with surfactants concentration.

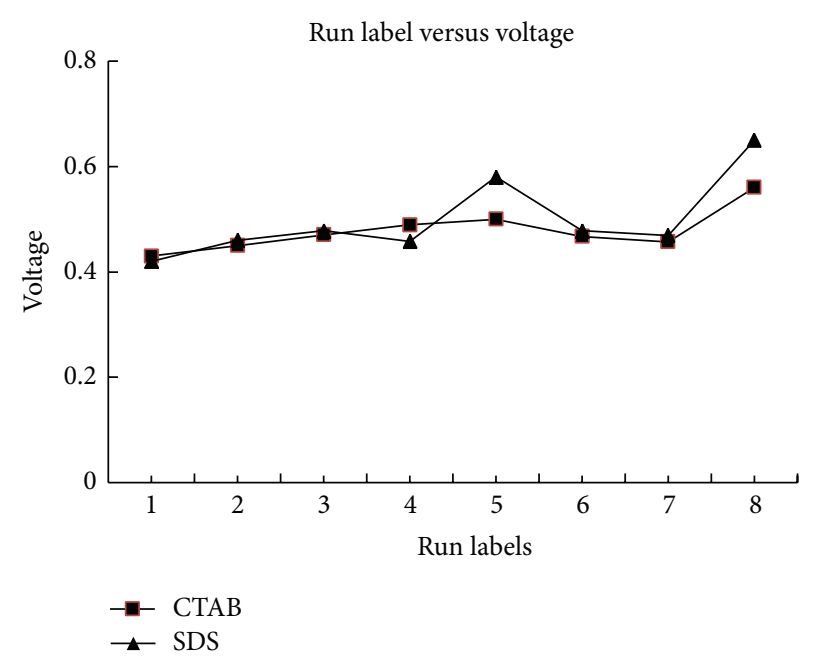

FIgURE 6: Voltage for different run labels.

4.2. Effect of Surfactants on Coating Thickness and Voltage. Figure 4 shows that the coating thickness was $11.25 \mu \mathrm{m} / \mathrm{hr}$ and $10.53 \mu \mathrm{m} / \mathrm{hr}$, when the SDS and CTAB concentrations were $1.2 \mathrm{~g} / \mathrm{L}$ and $1.5 \mathrm{~g} / \mathrm{L}$, respectively [2]. As per Figures 4 and 5, as the coating thickness increases, the open circuit voltage also increases from $0.43 \mathrm{~V}$ to $0.65 \mathrm{~V}$ and attains its maximum at $10.53 \mu \mathrm{m}$ and $11.25 \mu \mathrm{m}$ for CTAB and SDS and then the voltage decreases.

Since, the deposition rate increases with the increase in surfactant concentration, the coating thickness also increases with the increase in surfactant concentration. The contact angle decreased with an increase in surfactant concentration resulting in better and improved wettability of electroless $\mathrm{Cu}$ deposits on the substrate. The surface tension decreased with an increase in surfactant concentration resulting in better spreading of copper deposits on the substrate. Janczuk et al. [9] studied the surface free energy of fluorite in the presence of SDS and reported that as the concentration of surfactant

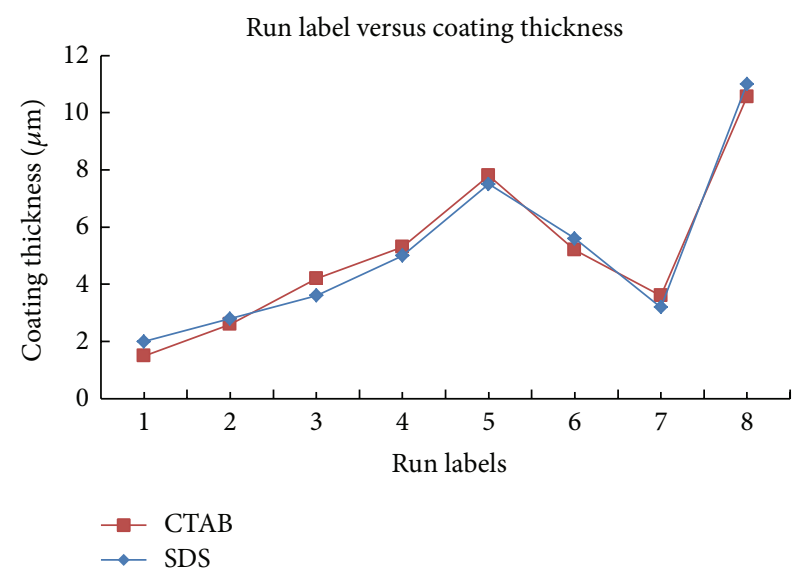

Figure 7: Coating thickness for different run labels.

increases, the SDS molecules at the solid/solution interface are adsorbed forming a stable monolayer. If this is the case, this could be a basis of an explanation for the delay in the initiation of the reaction as observed in the present study and hence less coating thickness. Kékicheff et al. [10] studied the effect of adsorption of CTAB on mica surfaces below critical micelle concentration and reported the formation of similar stable adsorbed layer at higher concentrations. In the presence of SDS and CTAB surfactants, the amount of copper deposited on the substrate surface steadily increases with the increase in surfactant concentration.

4.3. Variation of Coating Thickness and Voltage for Different DOE Run Labels. DOE was conducted using full factorial method and sample size was $2^{3}$. So, 8 experiments were conducted and the parameters such as voltage and coating thickness were measured. The coating thickness was measured using (Positector 6000). The voltage and current were measured using Multimeter (exitech) with Decade box arrangements under environmental conditions. From Figures 6 and 7, optimum results were obtained at the 8th run and the 5 th run, as the maximum voltage and coating thickness were obtained in those run labels.

4.4. Surface Morphology of Electroless Copper Deposits. The morphology of the deposits was analyzed by employing scanning electron microscope (SEM). The SEM micrographs of electroless copper deposits without surfactant and with surfactants SDS and CTAB are presented in Figures 8(a), 8(b), and $8(\mathrm{c})$, respectively. When the surfactant concentration is zero, the surface of the deposit consists of nonuniform deposition, and a fraction of copper particles deposited are less, when compared to the deposit with surfactants. With addition of surfactant, the amount of cu particle deposition is more. The reason is that the $\mathrm{Cu}$ particles produced inside the electrolyte are deposited on the substrate surface and that the surfactant addition does not allow the $\mathrm{Cu}$ particles to escape to the top surface and get deposited on a region other than the substrate surface. As the concentration of SDS 


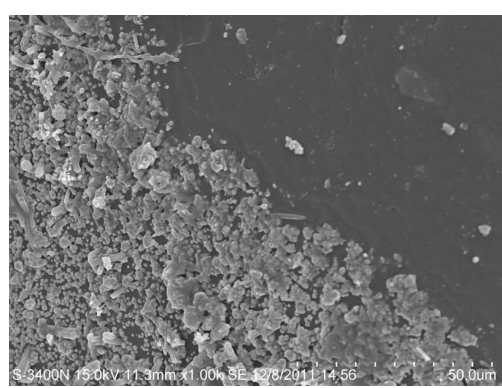

(a)

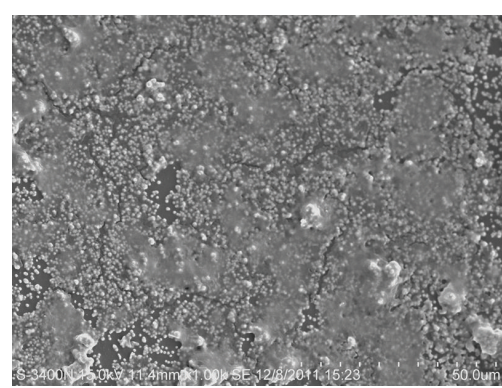

(b)

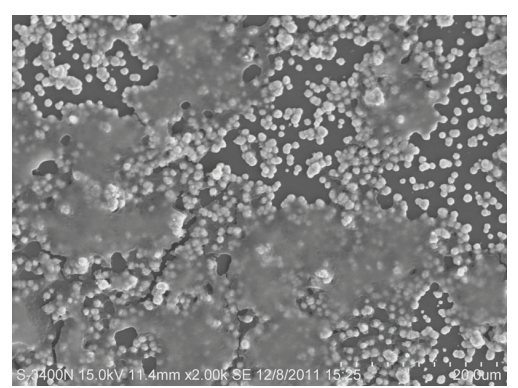

(c)

FiguRE 8: SEM image of copper coated on grid surface of solar cell: (a) without surfactant, (b) $1.2 \mathrm{~g} / \mathrm{L}$ of SDS, and (c) $1.5 \mathrm{~g} / \mathrm{L}$ of CTAB.

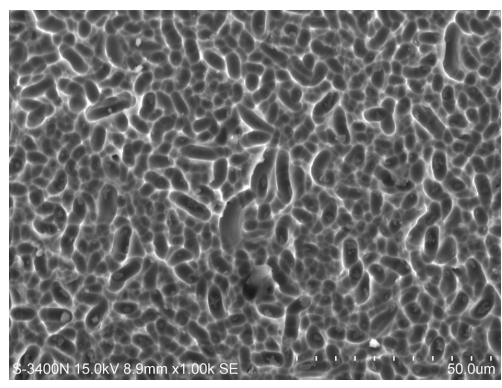

(a)

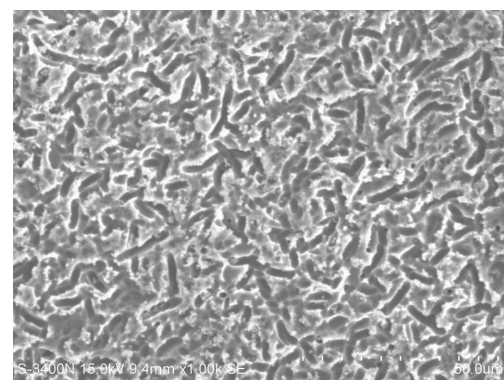

(b)

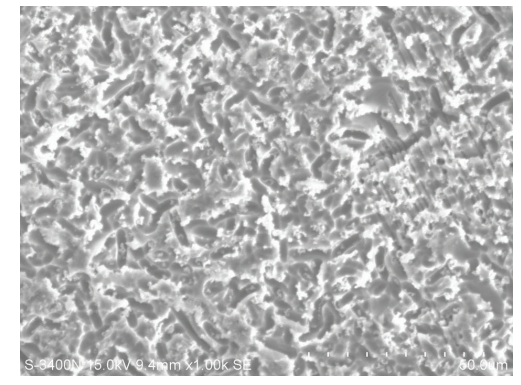

(c)

FIGURE 9: SEM image of copper coated on silicon surface of solar cell: (a) without surfactant, (b) 1.2 g/L of SDS, and (c) 1.5 g/L of CTAB.

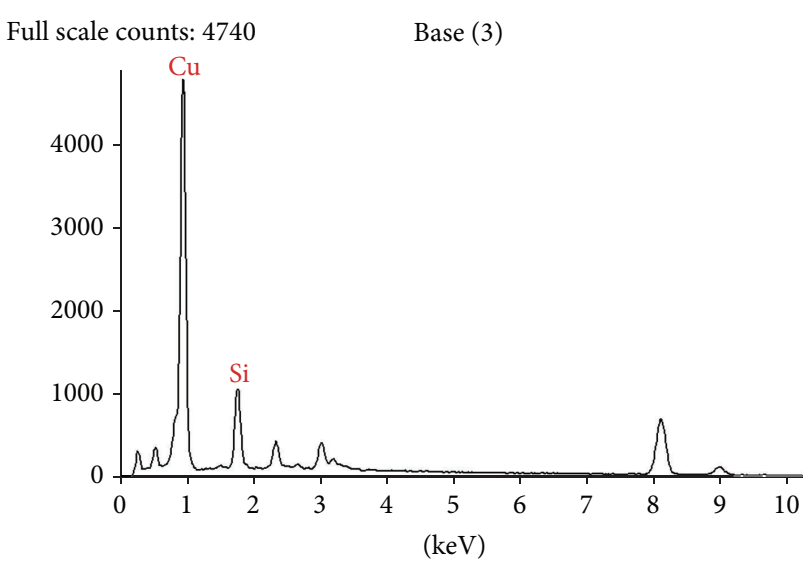

Live time: $30.0 \mathrm{sec}$

FIGURE 10: EDAX diffractogram of copper coated solar cell across the grid surface.

surfactant increases to $1.2 \mathrm{~g} / \mathrm{L}$, smooth surface is formed, and as the concentration of CTAB surfactant increases to $1.5 \mathrm{~g} / \mathrm{L}$, surface morphology is changed from nonsmooth nodular appearance to a smooth surface. It is interesting to note that in case of solar cell, there are two regions: one is the grid region which has metal surface made of silver and another is the silicon surface which is the semiconducting surface. Electroless deposition is favorable on the metal surface but the silicon surface is not thermodynamically favorable for electroless deposition. There is continuous deposition of

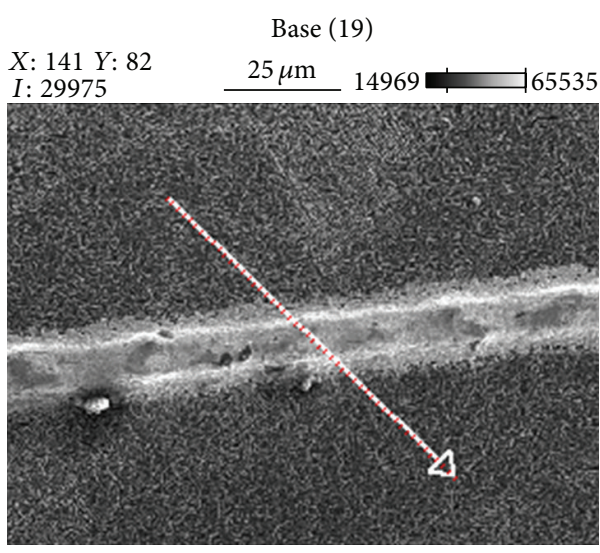

FIGURE 11: SEM image of copper coated solar cell across the grid.

copper particles on the grid surface and on the silicon layer; the copper particles are deposited only on the activated regions of silicon surface (i.e., dispersed). The copper deposits on the silicon surface without surfactant and with surfactant concentration are provided by the set of micrographs in Figures 9(a), 9(b), and 9(c).

4.5. Energy-Dispersive X-Ray Spectroscopy (EDAX) Analysis. Surface morphology and the cross-section of the sample were studied using SEM (Hitachi S-3400N) analysis, and the elemental composition of the sample was identified using 
TABLE 3: Elemental composition across the grid surface.

\begin{tabular}{|c|c|c|c|c|c|}
\hline Element line & Net counts & Net counts error & Weight \% & Atom \% & Formula \\
\hline $\mathrm{Si} \mathrm{K}$ & 9953 & \pm 158 & 23.59 & 41.13 & $\mathrm{Si}$ \\
\hline $\mathrm{Cu} \mathrm{K}$ & 12456 & \pm 238 & 76.41 & 58.87 & $\mathrm{Cu}$ \\
\hline $\mathrm{Cu} \mathrm{L}$ & 47259 & \pm 305 & - & - & \\
\hline Total & & & 100.00 & 100.00 & \\
\hline
\end{tabular}

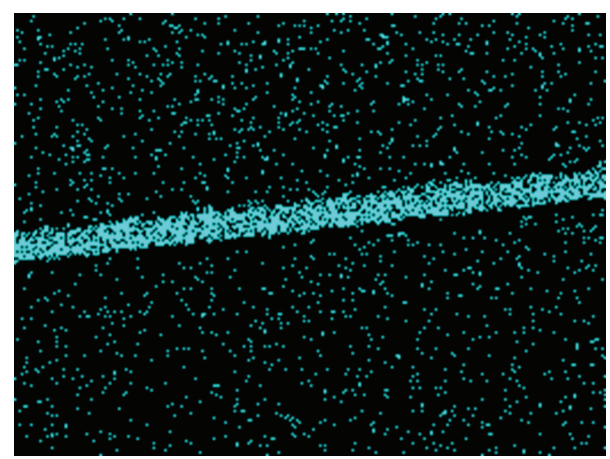

FIGURE 12: Mapping of deposition of cu particles on silicon surface and the grid.

energy-dispersive $\mathrm{x}$-ray spectroscopy (EDAX). Figure 10 shows the EDAX analysis of copper coated solar cell across the solar cell, and Table 3 shows the elemental composition across the grid surface. Figure 11 shows the SEM image of multicrystalline solar cell coated with copper and the arrow shows the direction which the EDAX analysis has taken. The white continuous layer is the copper deposition on the grid layer with the elemental composition of $58.87 \%$ and the silicon composition of $41 \%$ along the arrow direction.

Figure 12 shows the mapping of the copper coated silicon wafer showing the compactness of the $\mathrm{Cu}$ particles with the dense layer of copper on the grid lines and uniform dispersion of copper particles on the silicon surface. The roughness of the multicrystalline silicon wafer of $0.68 \mu \mathrm{m}$ has increased to $0.81 \mu \mathrm{m}$ [11] for SDS at $1.2 \mathrm{~g} / \mathrm{L}$ and $0.95 \mu \mathrm{m}$ for CTAB at $1.5 \mathrm{~g} / \mathrm{L}$, when the copper particle size of 80 to $120 \mathrm{~nm}$ was dispersed on the silicon surface as in Figure 13. The roughness of grid surface has increased to $1.34 \mu \mathrm{m}$ and $1.56 \mu \mathrm{m}$ for SDS and CTAB at its CMC level. These copper particles dispersed on the surface will act as an antireflection coating which makes multiple reflections within the particles and reduces the scattering of light on the silicon surface. The copper deposited on the grid lines has good adhesion property and uniformity due to the effect of surfactants. This coating of copper improves the antibacterial properties and corrosion strength of the cell when it is exposed to atmospheric conditions. Since the conduction properties of copper are very near to the silver, an attempt can be made to replace the silver grid by copper in future.

Figure 14(a) shows the mapping of copper coated silicon surface without surfactant addition to the electroless copper bath. It is interesting to note that in the case of electroless copper deposit without surfactant, the dispersion of $\mathrm{Cu}$

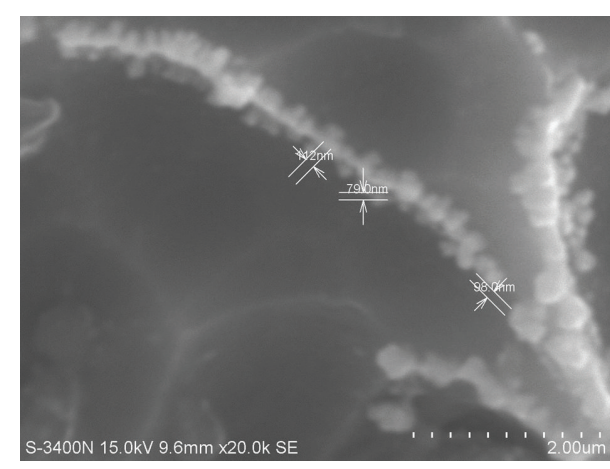

FIGURE 13: SEM image showing the size of copper nanoparticles on silicon surface at 20,000X.

TABLE 4: Analysis of variance for open circuit voltage (volts).

\begin{tabular}{lccc}
\hline Source & Adj MS & $F$ & $P$ \\
\hline Main effects & 0.010829 & 17.68 & 0.054 \\
pH & 0.00183 & 2.99 & 0.226 \\
$\begin{array}{l}\text { Temperature } \\
\begin{array}{l}\text { Surfactant } \\
\text { concentration (SDS) }\end{array}\end{array}$ & $\mathbf{0 . 0 1 6 2 9}$ & $\mathbf{2 6 . 5 9}$ & $\mathbf{0 . 0 3 6}$ \\
$\begin{array}{l}\text { 2-way interactions } \\
\text { pH } * \text { surfactant }\end{array}$ & 0.003438 & 5.61 & 0.151 \\
$\begin{array}{l}\text { concentration (SDS) } \\
\begin{array}{l}\text { Temperature } * \text { surfactant } \\
\text { concentration (SDS) }\end{array}\end{array}$ & 0.000435 & 0.71 & 0.488 \\
Residual error & 0.006441 & 10.51 & 0.083 \\
\hline
\end{tabular}

particles seems to be less (Figure 14(a)) when compared to deposit with surfactant. With the addition of surfactant, the amount of $\mathrm{Cu}$ particle deposition is more. The reason is that the $\mathrm{Cu}$ particles produced inside the electrolyte are deposited on the activated substrate surface and that surfactant addition does not allow the $\mathrm{Cu}$ particles to escape to the top surface and get deposited on a region other than the substrate surface. Evidence is provided in Figures 14(b) and 14(c); as the surfactant concentration increases from $0.15 \mathrm{~g} / \mathrm{L}$, the amount of $\mathrm{Cu}$ particles deposited also increases and there is a steep increase in $0.75 \mathrm{~g} / \mathrm{L}$ of SDS surfactant and the deposition rate becomes constant after $1.2 \mathrm{~g} / \mathrm{L}$ of SDS since it attains its critical micelle concentration. Below the CMC, the addition of surfactant to an aqueous solution causes an increase in the number of charge carriers ((aq) $\mathrm{Na}^{+}$and (aq) ${ }^{-} \mathrm{OSO}_{3} \mathrm{Cl}_{2} \mathrm{H}_{25}$ ) and, consequently, an increase in the conductivity. Above the 


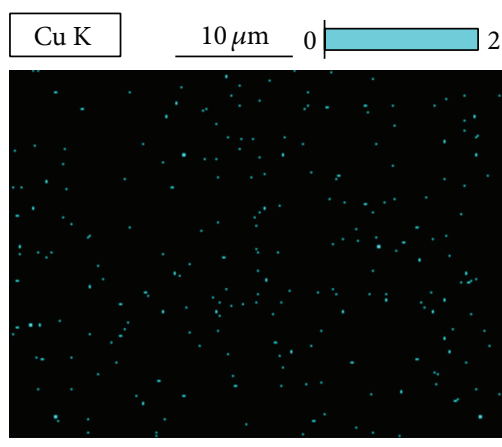

(a)

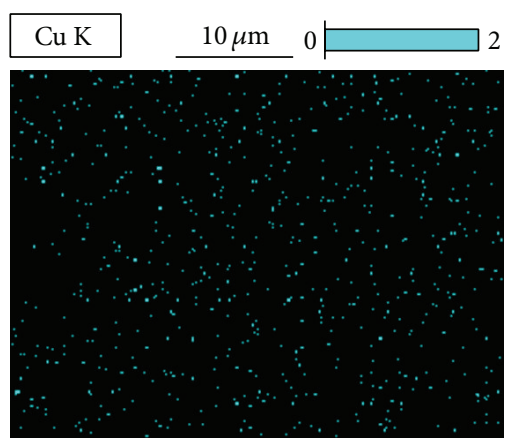

(b)

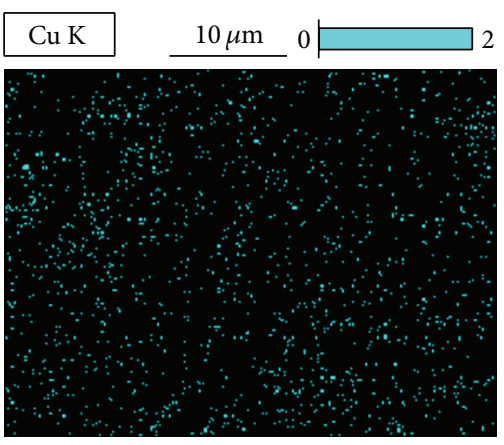

(c)

FIGURE 14: Mapping of copper coated silicon surface with surfactant SDS: (a) without surfactant, (b) $0.75 \mathrm{~g} / \mathrm{L}$, and (c) $1.2 \mathrm{~g} / \mathrm{L}$.

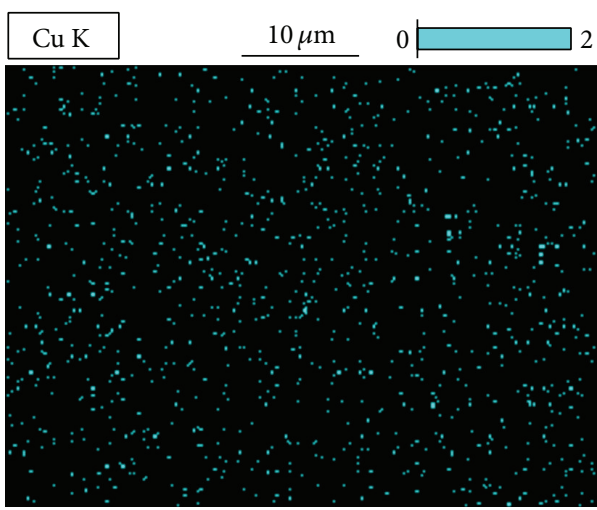

(a)

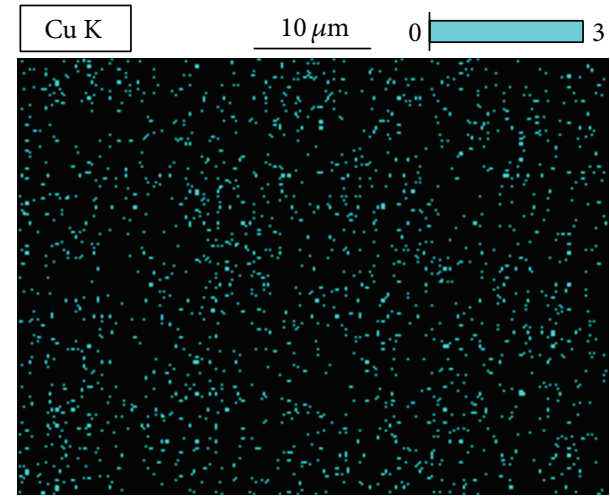

(b)

FIgURE 15: Mapping of copper coated silicon surface with surfactant CTAB: (a) $1.05 \mathrm{~g} / \mathrm{L}$ and (b) $1.5 \mathrm{~g} / \mathrm{L}$.

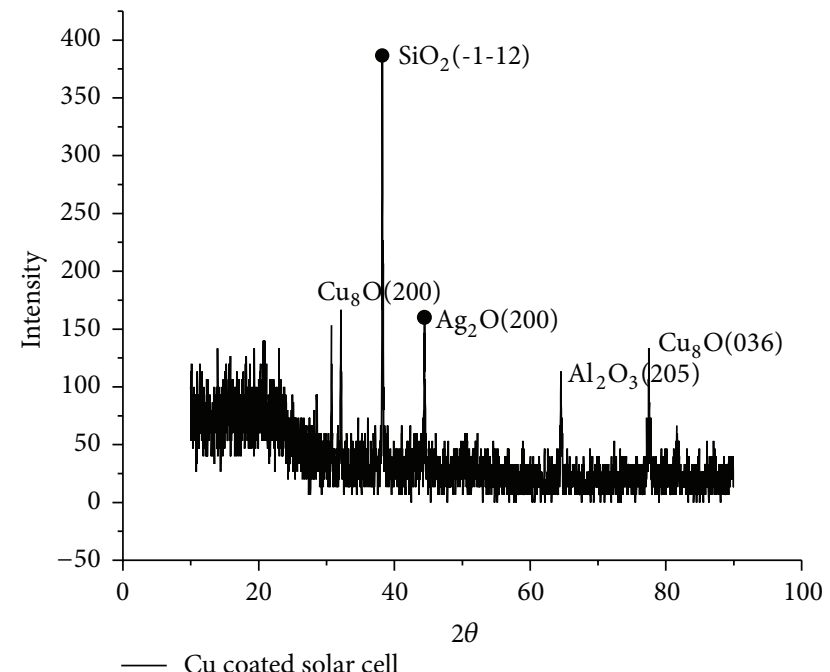

FIGURE 16: XRD of copper coated PV cell.

CMC, further addition of surfactant increases the micelle concentration while the monomer concentration remains approximately constant (at the CMC level). Since a micelle
TABLE 5: Analysis of variance for coating thickness ( $\mu \mathrm{m})$.

\begin{tabular}{lcccc}
\hline Source & DF & Adj MS & $F$ & $P$ \\
\hline Main effects & 3 & 17.688 & 14.37 & 0.066 \\
pH & 1 & 2.531 & 2.06 & 0.288 \\
$\begin{array}{l}\text { Temperature } \\
\begin{array}{l}\text { Surfactant } \\
\text { concentration (SDS) }\end{array}\end{array}$ & 1 & 12.251 & 9.95 & 0.088 \\
$\begin{array}{l}\text { 2-way interactions } \\
\text { pH } * \text { surfactant }\end{array}$ & 2 & 3.031 & 2.46 & 0.289 \\
$\begin{array}{l}\text { concentration (SDS) } \\
\text { Temperature } *\end{array}$ & 1 & 1.711 & 1.39 & 0.36 \\
$\begin{array}{l}\text { surfactant concentration } \\
\text { (SDS) }\end{array}$ & 1 & 4.351 & 3.53 & 0.201 \\
Residual error & 2 & 1.231 & & \\
\hline Total & 7 & & & \\
\hline
\end{tabular}

is much larger than a SDS monomer, it diffuses more slowly through solution, and so it is a less efficient charge carrier.

As the concentration of CTAB surfactant increases from $0.75 \mathrm{~g} / \mathrm{L}$, the amount of copper particles deposited also increases and there is a steep increase at $1.05 \mathrm{~g} / \mathrm{L}$ as shown 
Main effects plot for open circuit voltage (V)

Data means
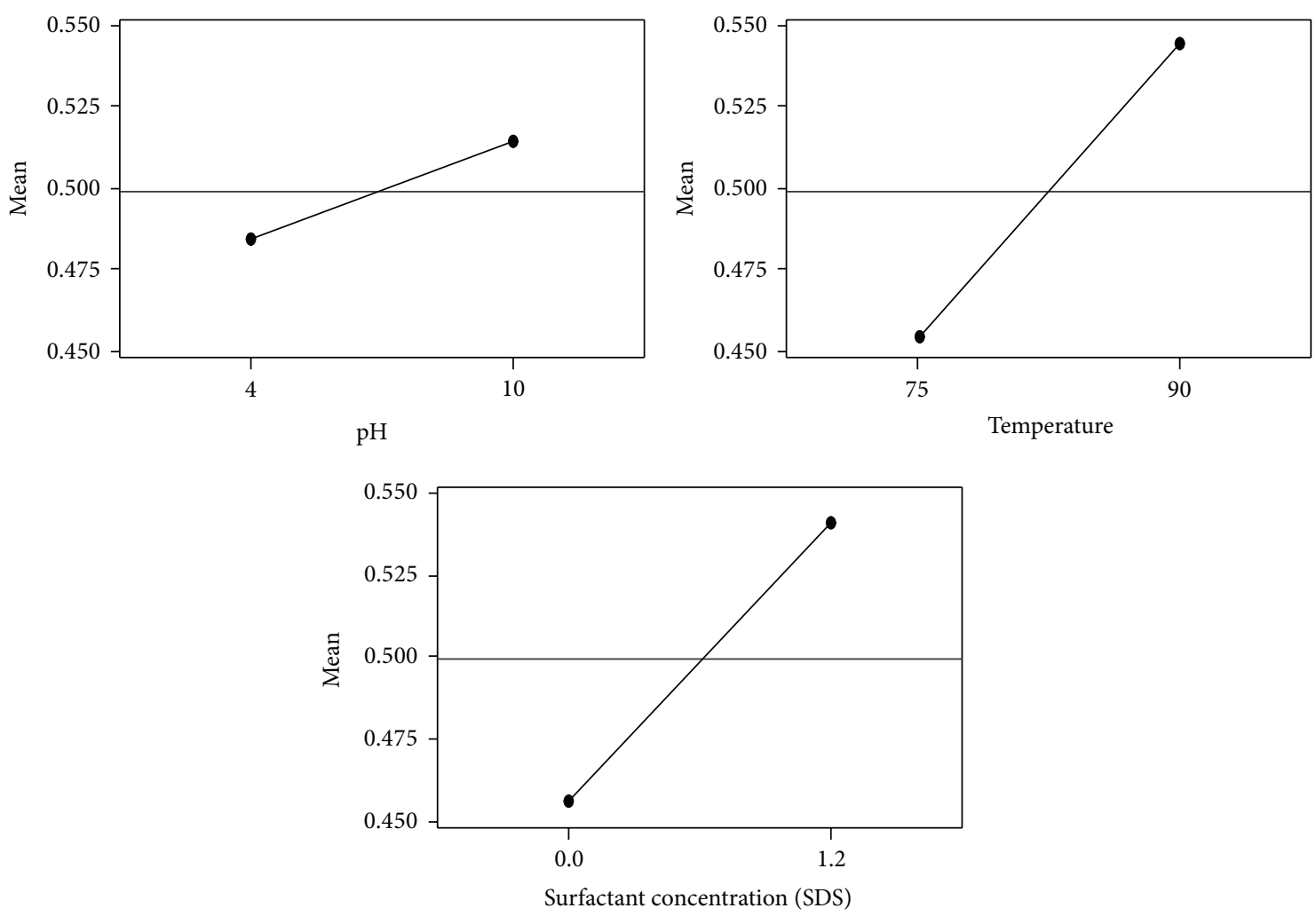

FIGURE 17: Main effects plot for open circuit voltage.

Main effects plot for coating thickness $(\mu \mathrm{m})$

Data means
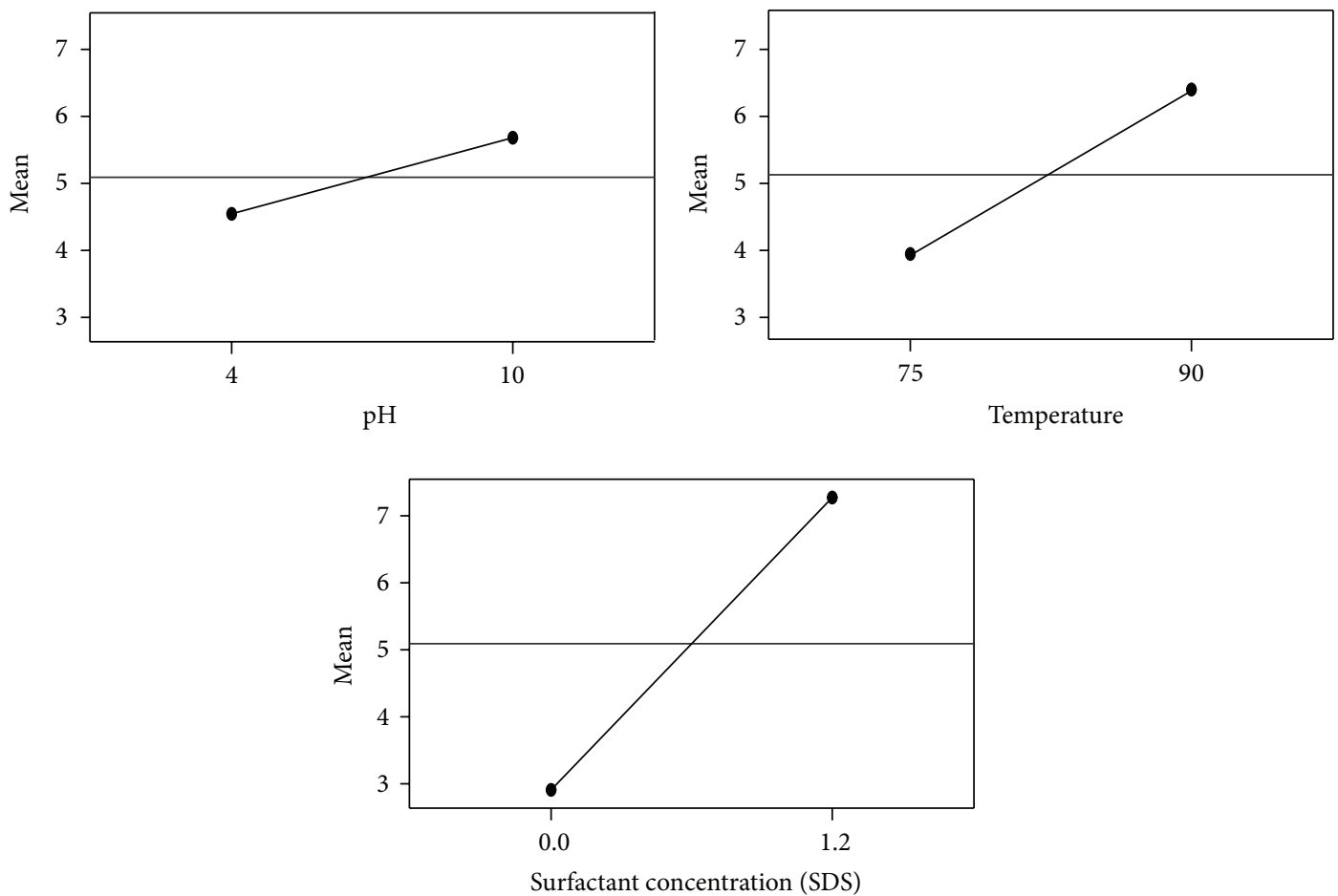

FIGURE 18: Main effects plot for open circuit voltage. 


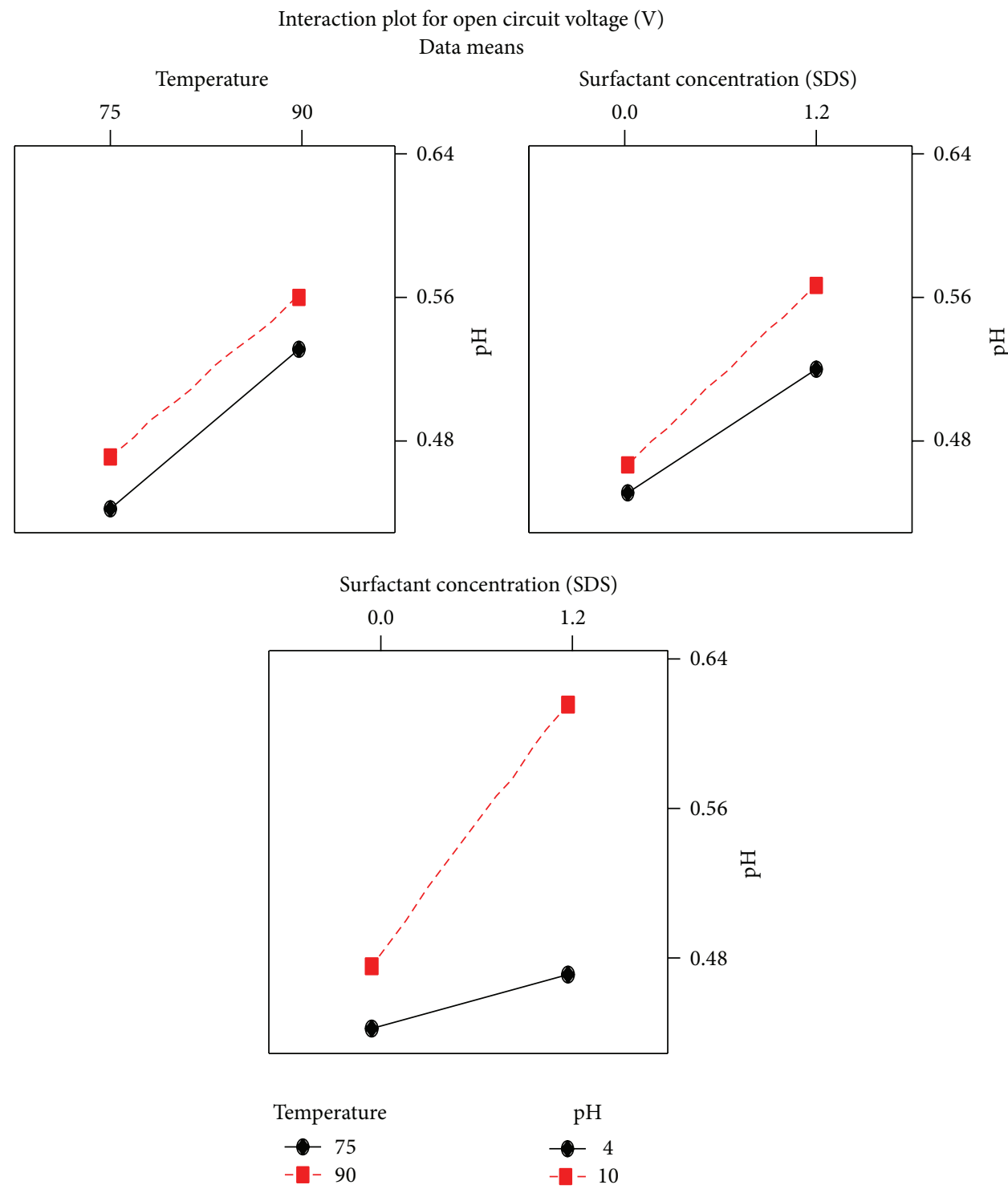

FIGURE 19: Interaction plot for open circuit voltage.

in Figure 15(a) and the CMC level was attained at $1.5 \mathrm{~g} / \mathrm{L}$, and hence there is no increase in deposition rate. The mapping of copper coated silicon surface at $1.5 \mathrm{~g} / \mathrm{L}$ of surfactant CTAB shows a greater number of copper particles deposited than that of the surfactant at $1.05 \mathrm{~g} / \mathrm{L}$.

4.6. XRD Analysis. The XRD analysis was made using (RIGAKU ULTIMA IV) $\mathrm{x}$-ray diffractometer, and Figure 16 shows the XRD pattern of copper coated multicrystalline solar cell showing $\mathrm{SiO}_{2}$ corresponding to the (JCPDS 01-082-1576) and the presence of copper in the form of $\mathrm{Cu}_{8} \mathrm{O}(200)$ (JCPDS-78-1588) and $\mathrm{Cu}_{8} \mathrm{O}(036)$ (JCPDS-781588) corresponding to the peak at 2-theta value of 32.7370 and 77.552 , respectively. As for the future work, the presence of oxide can be reduced by selecting proper plating solution which will further improve the efficiency.

\section{Analysis of Full Factorial Design}

\subsection{Analysis of Full Factorial Design for SDS Surfactant}

5.1.1. Main Effect Plot. The importance of main effect plot is that it shows the behavior of the system when one parameter is varied by keeping another parameter constant [6]. A main effect occurs when the mean response changes across the levels of a factor and it can be used to compare the relative strength of the effects across each factor. It can be inferred from the plot (Figure 17) that the $\mathrm{pH}$, temperature, and surfactant (SDS) concentration have positive effect on the open 


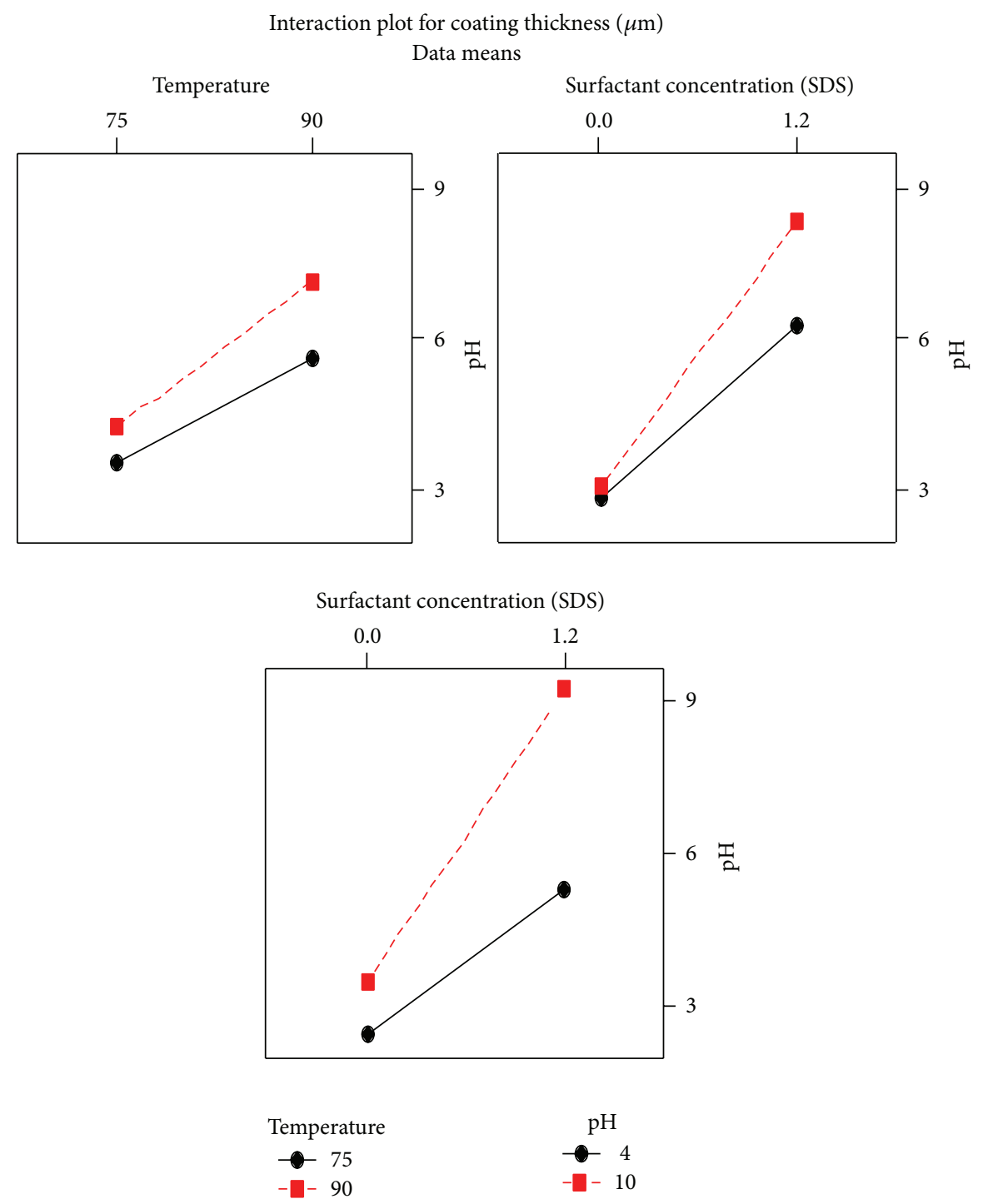

Figure 20: Interaction plot for coating thickness.

circuit voltage. It can also be concluded that temperature and the surfactant concentration have profound effect on the open circuit voltage.

It can be inferred from the plot (Figure 18) that the $\mathrm{pH}$, temperature, and surfactant (SDS) concentration have positive effect on the coating thickness and that the surfactant concentration has profound effect on the coating thickness which is indicated by the vertical nature of the line.

5.1.2. Interaction Plot. The interaction plot gives an average output for each level of the factors with the level of the second factor held constant [6]. These plots are used to interpret significant interactions between the process parameters. Interaction is present when the response at a factor level depends upon the levels of other factors. Since they can magnify or diminish the main effects of the parameters, evaluating interactions is extremely important.

In the interaction plot for open circuit voltage, as shown in Figure 19, the lines in $\mathrm{pH}$ versus temperature are approximately parallel, indicating a lack of interaction between these factors and hence, it suggests that mutual interaction between these factors has a negligible effect on the voltage. Similarly, the interaction plot of surfactant concentration versus $\mathrm{pH}$ and temperature shows that there is synergic interaction between them. Although the lines on the plot do not cross each other, the lack of parallelism of the lines exhibits significant interaction.

From Table 4, the $P$ value of temperature and surfactant concentration is less than the chosen value of $\alpha=0.05$ for the analysis, and hence it has significant effect on the output open circuit voltage. 
Main effects plot for open circuit voltage (V)

Data means
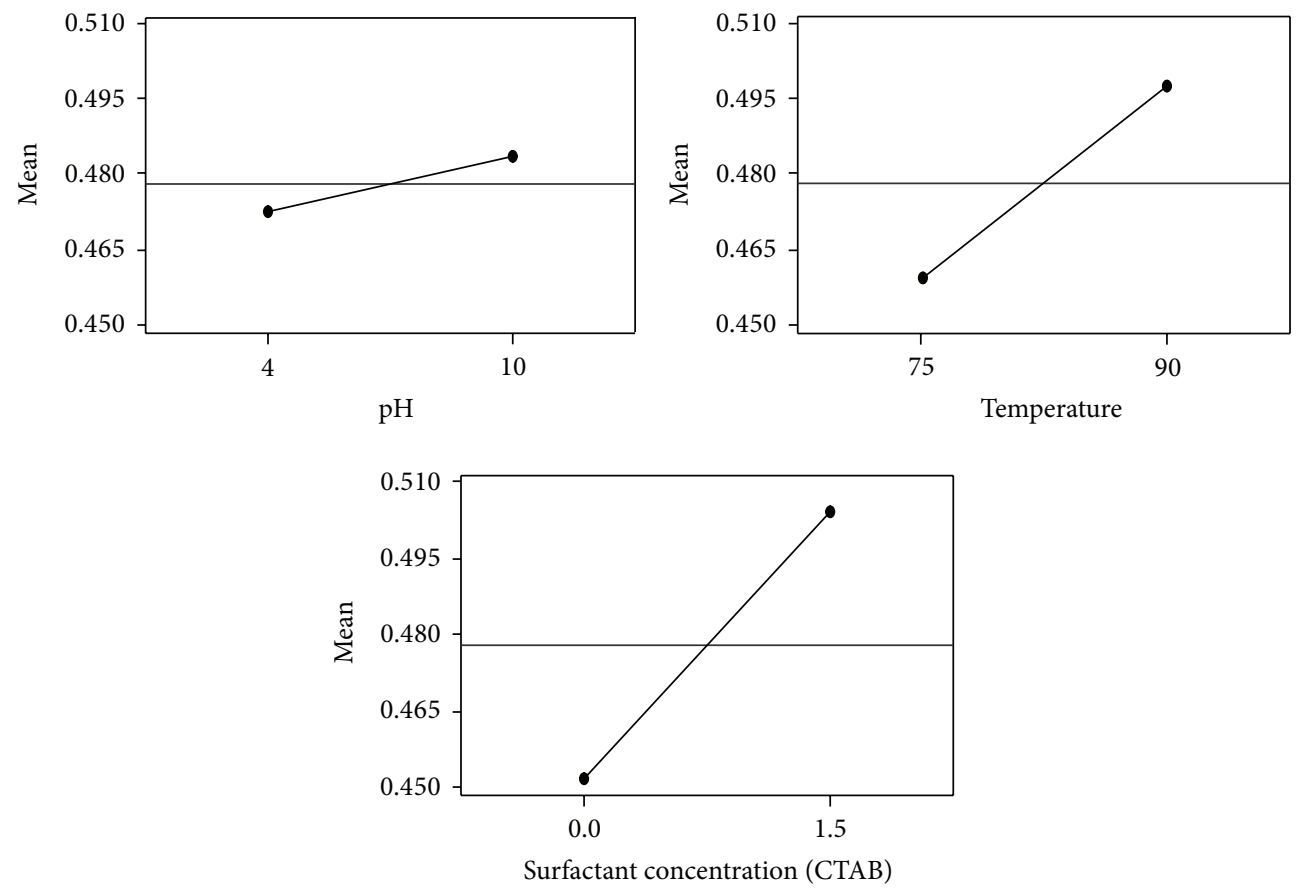

FIGURE 21: Main effects plot for open circuit voltage.

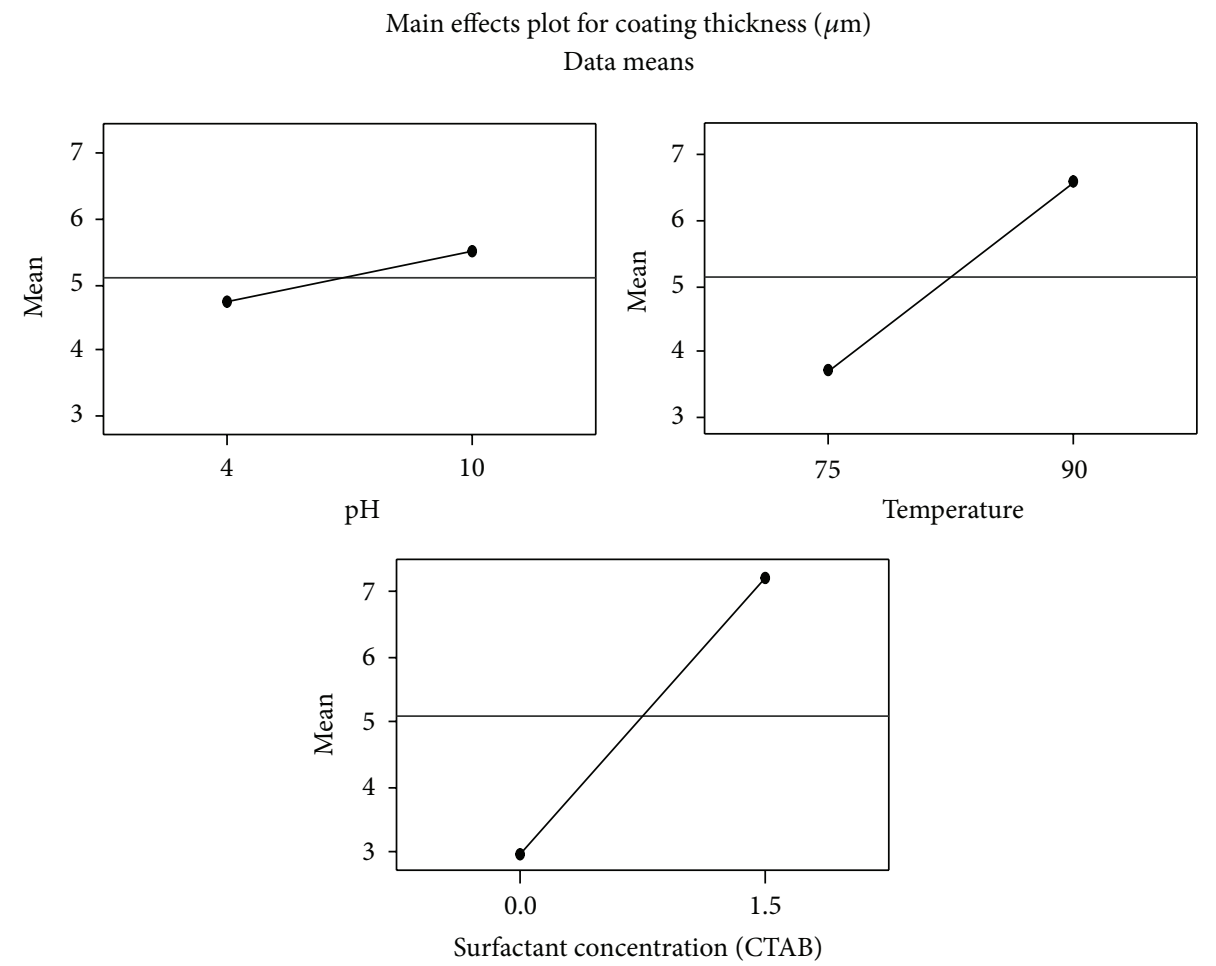

Figure 22: Main effects plot for coating thickness. 


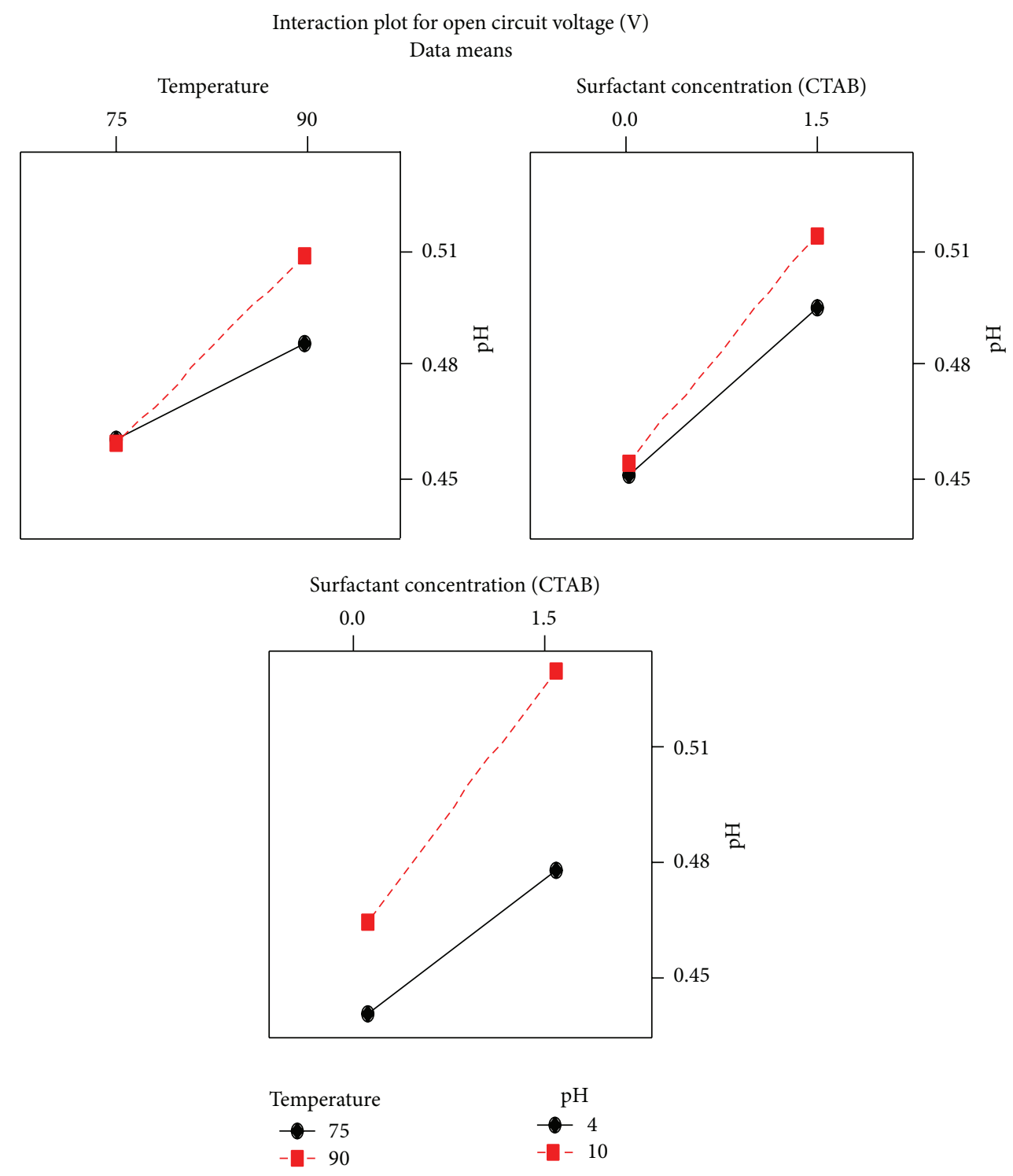

FIGURE 23: Interaction plot for open circuit voltage.

In the interaction plot for coating thickness, as shown in Figure 20, the lines in $\mathrm{pH}$ versus temperature and temperature surfactant concentration have synergic interaction which is indicated by the lack of parallelism of the lines. From Table 5, the $P$ value of the surfactant (SDS) is 0.031 which is less than the chosen value of $\alpha=0.05$ for analysis; hence, the effect of surfactant SDS is significant in the process to influence the coating thickness.

\subsection{Analysis of Full Factorial Design for CTAB Surfactant}

5.2.1. Main Effect Plot. It can be inferred from the plot (Figure 21) that the $\mathrm{pH}$, temperature, and surfactant (CTAB) concentration have positive effect on the open circuit voltage. It can also be concluded that temperature and the surfactant concentration have profound effect on the open circuit voltage.
It can be inferred from the plot (Figure 22) that the $\mathrm{pH}$, temperature, and surfactant (CTAB) concentration have positive effect on the coating thickness. It can also be concluded that temperature and the surfactant concentration have profound effect on the coating thickness.

5.2.2. Interaction Plot. Although the lines on the plot do not cross each other, the lack of parallelism of the lines exhibits significant interaction. The greater the departure of the lines from the parallel state, the higher the degree of interaction [6]. From the interaction plot of open circuit voltage (Figure 23) and coating thickness (Figure 24), surfactant concentration versus $\mathrm{pH}$ shows interaction but at the lower data means values. The temperature versus surfactant shows only the lack of parallelism, that is, synergic interaction.

From Table 6 , the $P$ value of the surfactant (CTAB) is 0.041 which is less than the chosen value of $\alpha=0.05$ for 


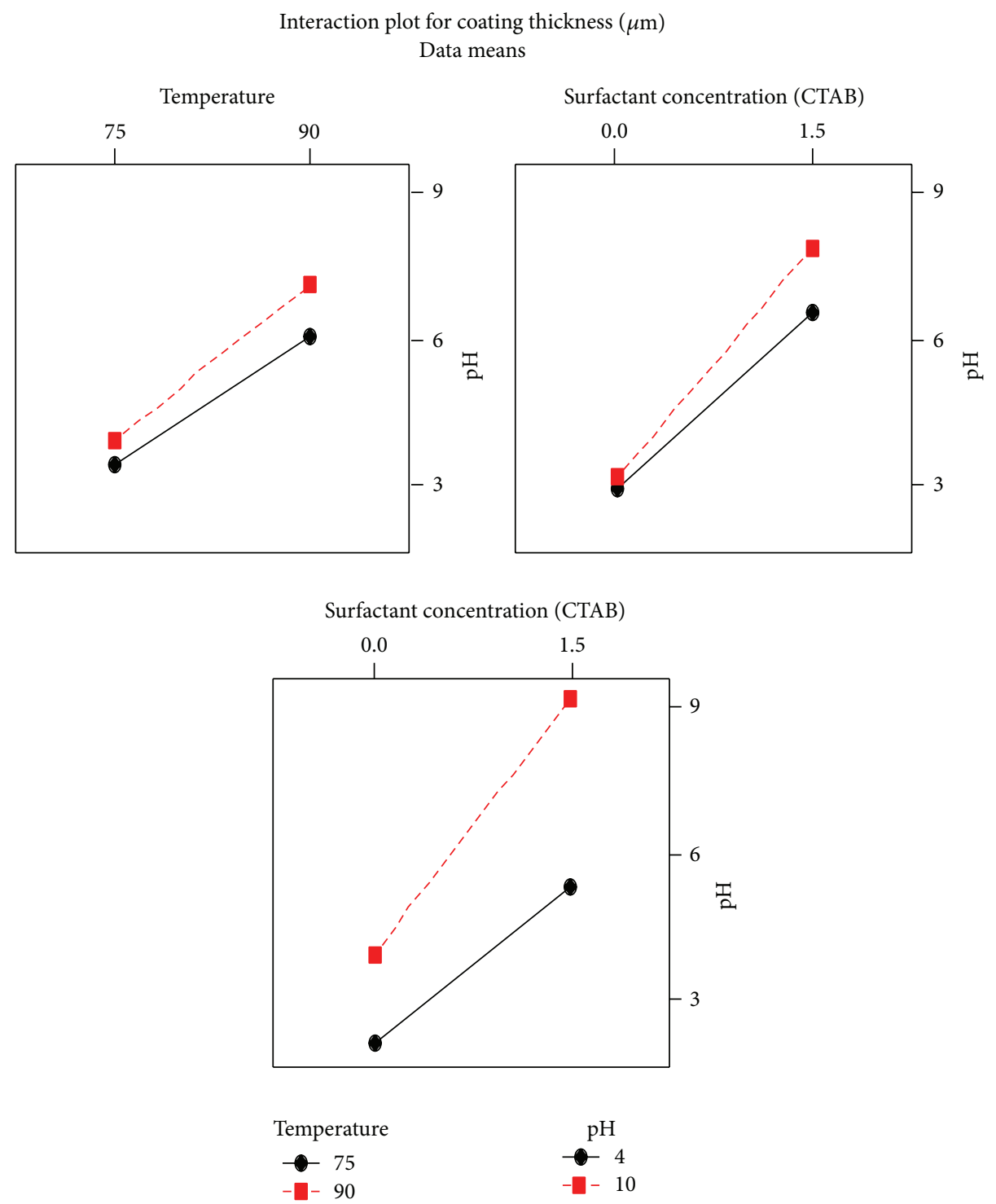

FIGURE 24: Interaction plot for coating thickness.

TABLE 6: Analysis of variance for coating thickness $(\mu \mathrm{m})$.

\begin{tabular}{lcccc}
\hline Source & DF & Adj MS & $F$ & $P$ \\
\hline Main effects & 3 & 17.9428 & 11.34 & 0.082 \\
pH & 1 & 1.2403 & 0.78 & 0.469 \\
Temperature & 1 & 16.6753 & 10.54 & 0.083 \\
Surfactant & & $\mathbf{3 5 . 9 1 2 8}$ & $\mathbf{2 2 . 6 9}$ & $\mathbf{0 . 0 4 1}$ \\
concentration (CTAB) & $\mathbf{1}$ & & & \\
2-way interactions & 2 & 1.1591 & 0.73 & 0.577 \\
pH $*$ temperature & 1 & 0.1653 & 0.1 & 0.777 \\
Temperature $*$ & & & & \\
surfactant concentration & 1 & 2.1528 & 1.36 & 0.364 \\
(CTAB) & & & & \\
Residual error & 2 & 1.5828 & & \\
\hline Total & 7 & & & \\
\hline
\end{tabular}

TABLE 7: Analysis of variance for open circuit voltage (volts).

\begin{tabular}{lcccc}
\hline Source & DF & Adj MS & $F$ & $P$ \\
\hline Main effects & 3 & 0.002855 & 2.77 & 0.276 \\
pH & 1 & 0.000253 & 0.25 & 0.669 \\
Temperature & 1 & 0.00285 & 2.77 & 0.238 \\
$\begin{array}{l}\text { Surfactant } \\
\text { concentration (CTAB) }\end{array}$ & $\mathbf{1}$ & $\mathbf{0 . 0 0 5 4 6}$ & $\mathbf{5 . 3}$ & $\mathbf{0 . 1 4 8}$ \\
2-way interactions & 2 & 0.00021 & 0.2 & 0.831 \\
pH * temperature & 1 & 0.0003 & 0.29 & 0.643 \\
pH * surfactant & 1 & 0.00012 & 0.12 & 0.765 \\
concentration (CTAB) & & 0.00103 & & \\
Residual error & 2 & & & \\
\hline Total & 7 & & &
\end{tabular}


analysis; hence, the effect of surfactant CTAB is significant in the process to influence the coating thickness. In case of open circuit voltage there is no factor, which is strongly influencing the output voltage. It is clearly indicated by the $P$ values in Table 7 whose values are greater than 0.05 . From the DOE results obtained by varying the surfactants, the use of surfactant SDS shows better results in case of coating thickness and voltage when compared to the use of CTAB. The $P$ value in case of surfactant SDS is less than 0.05 for open circuit voltage and coating thickness showing its significant effect on the process.

\section{Conclusion}

When $\mathrm{pH}$ was 8-9, the coating thickness was a maximum of $12 \mu \mathrm{m}$ and $11.63 \mu \mathrm{m}$, and it was a minimum of $3 \mu \mathrm{m}$ and $2.6 \mu \mathrm{m}$, when $\mathrm{pH}$ was at $4-5$ for SDS and CTAB, respectively. The increase in coating thickness with respective increase in temperature up to $85^{\circ} \mathrm{C}(12 \mu \mathrm{m})$ and the further increase in temperature destabilize the electroless bath. When temperature was $90^{\circ} \mathrm{C}$, the coating thickness was reduced to $8 \mu \mathrm{m}$ and $7.6 \mu \mathrm{m}$.

The coating thickness was $11.25 \mu \mathrm{m} / \mathrm{hr}$ and $10.53 \mu \mathrm{m} / \mathrm{hr}$ when the SDS and CTAB concentrations were $1.2 \mathrm{~g} / \mathrm{L}$ and $1.5 \mathrm{~g} / \mathrm{L}$, respectively. When the coating thickness increases, the open circuit voltage also increases from 0.43 volts to 0.65 volts and attains its maximum at $10.53 \mu \mathrm{m}$ and $11.25 \mu \mathrm{m}$ for $\mathrm{CTAB}$ and SDS and then the voltage decreases.

DOE was conducted using full factorial method and sample size was $2^{3}$. Eight experiments were conducted and optimum results were obtained at the 5th run and 8th run, as the maximum voltage of 0.58 volts and 0.65 volts was obtained in those run labels, respectively, for SDS. Another set of 8 experiments were conducted with CTAB as surfactant and the optimum results were obtained at the 8th and 5th run as the maximum voltage of 0.56 volts and 0.50 volts was obtained in those run labels, respectively.

The $P$ value in case of surfactant SDS is less than 0.05 for open circuit voltage and coating thickness showing its significant effect on the process, when compared to the surfactant CTAB.

\section{Conflict of Interests}

The authors declare that there is no conflict of interests regarding the publication of this paper.

\section{Acknowledgments}

The authors extend their sincere thanks to the Centre for Electrochemical Research Institute (CECRI), Karaikudi, for coating thickness and surface roughness measurements. The authors extend their thanks to their electronics and communication engineering department for voltage measurements.

\section{References}

[1] R. Wolf, Electroless Plating, ASM International, Materials Park, Ohio, USA, 1991.
[2] R. Elansezhian, B. Ramamoorthy, and P. K. Nair, "The influence of SDS and CTAB surfactants on the surface morphology and surface topography of electroless Ni-P deposits," Journal of Materials Processing Technology, vol. 209, no. 1, pp. 233-240, 2009.

[3] B. Kavitha and M. Dhanam, "Determination of optimum film thickness and composition of $\mathrm{Cu}(\mathrm{InAl}) \mathrm{Se}_{2}$ thin films as an absorber for solar cell applications," World Journal of Nano Science and Engineering, vol. 1, pp. 108-118, 2011.

[4] B. C. Tripathy, S. C. Das, G. T. Hefter, and P. Singh, "Electro winning from acidic sulfate solution-part I: effects of sodium lauryl sulfate," Journal of Applied Electrochemistry, vol. 27, no. 6, pp. 673-678, 1997.

[5] J. Medina-Valtierra, C. Frausto-Reyes, S. Calixto, P. Bosch, and V. H. Lara, "The influence of surfactants on the roughness of titania sol-gel films," Materials Characterization, vol. 58, no. 3, pp. 233-242, 2007.

[6] A. Kukreja, P. Chopra, A. Aggarwal, and P. Khanna, "Application of full factorial design for optimization of feed rate of stationary hook hopper," International Journal of Modeling and Optimization, vol. 1, no. 3, 2011.

[7] Y. C. Ee, Z. Chen, L. Chan et al., "Effect of processing parameters on electroless $\mathrm{Cu}$ seed layer properties," Thin Solid Films, vol. 462-463, pp. 197-201, 2004.

[8] F. Hanna, Z. Abdel Hamid, and A. Abdel Aal, "Controlling factors affecting the stability and rate of electroless copper plating," Materials Letters, vol. 58, no. 1-2, pp. 104-109, 2003.

[9] B. Jańczuk, M. L. González-martín, and J. M. Bruque, "Wettability of fluorite in the presence of an anionic and a non-ionic surfactant," Canadian Metallurgical Quarterly, vol. 35, no. 1, pp. 17-21, 1996.

[10] P. Kékicheff, H. K. Christenson, and B. W. Ninham, "Adsorption of cetyltrimethylammonium bromide to mica surfaces below the critical micellar concentration," Colloids and Surfaces, vol. 40, pp. 31-41, 1989.

[11] A. Bahrami, S. Mohammadnejad, N. J. Abkenar, and S. Soleimaninezhad, "Optimized single and double layer antireflection coatings for GaAs solar cells," International Journal of Renewable Energy Research, vol. 3, no. 1, 2013. 

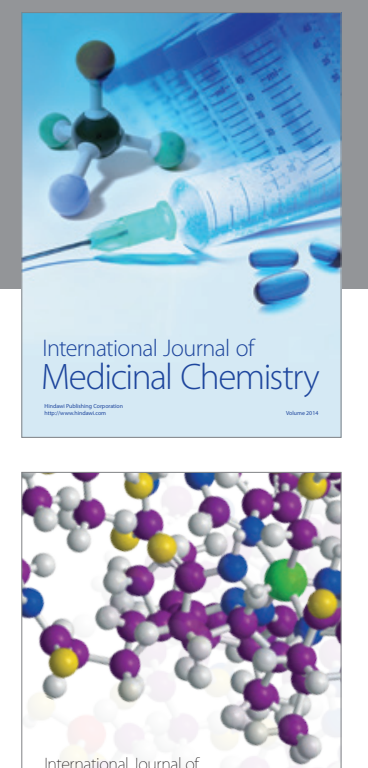

\section{Carbohydrate} Chemistry

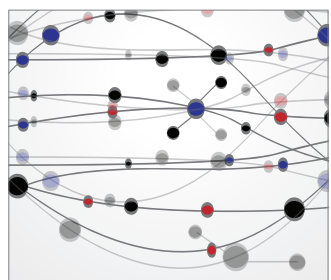

The Scientific World Journal
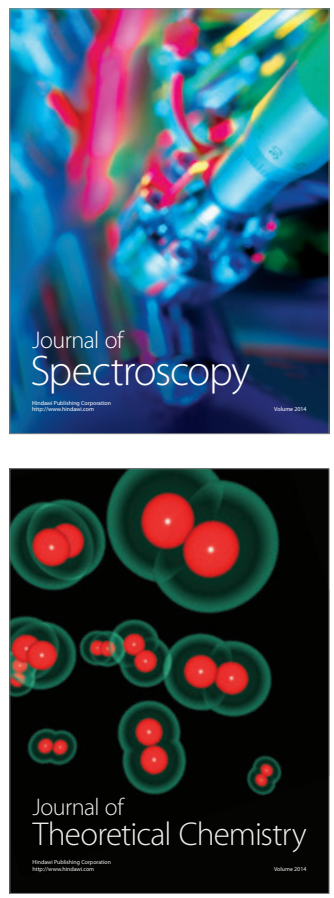
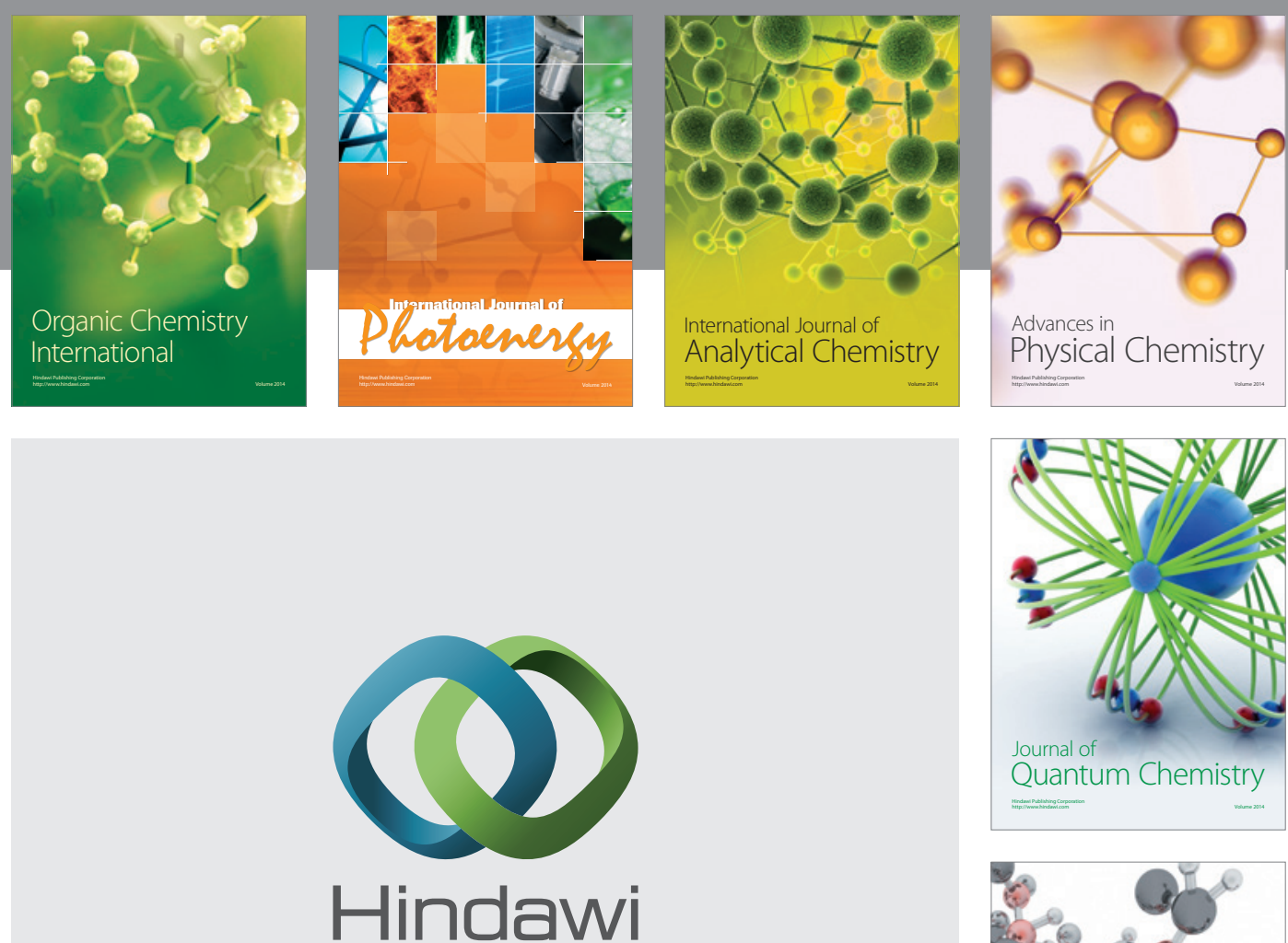

Submit your manuscripts at

http://www.hindawi.com

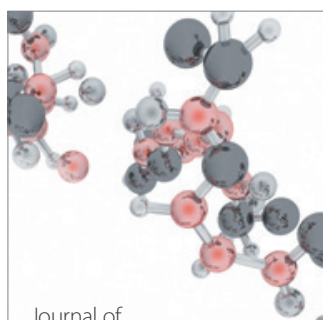

Analytical Methods

in Chemistry

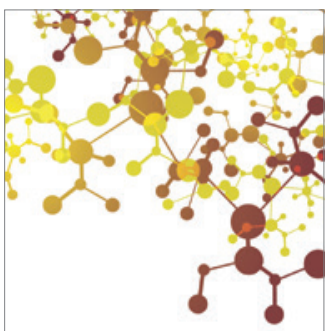

Journal of

Applied Chemistry

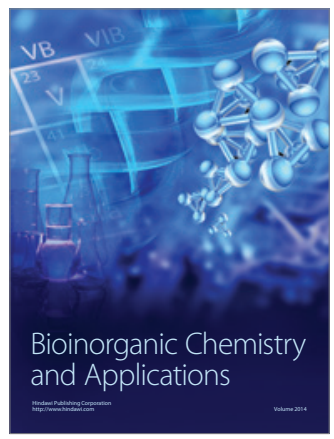

Inorganic Chemistry
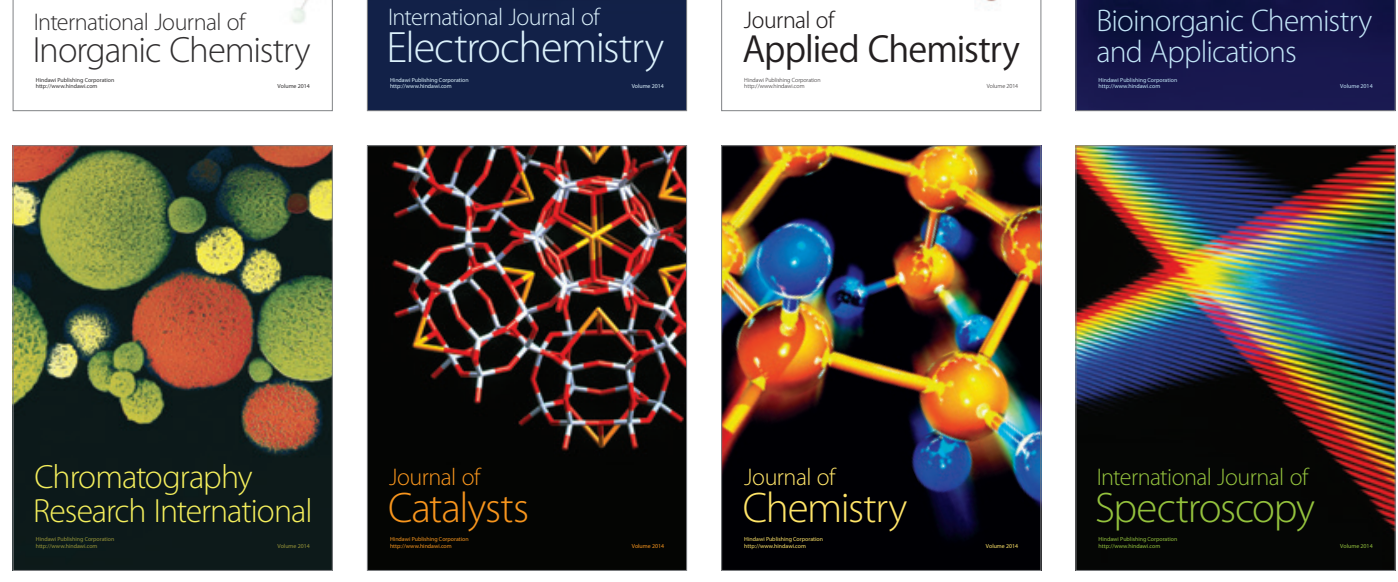